\title{
Protective effects of red ginseng according to steaming time on $\mathrm{HCl} /$ ethanol-induced acute gastritis
}

\author{
Joo Young Lee ${ }^{1}$ (1) $\cdot$ O Jun Kwon ${ }^{2} \cdot$ Jeong Sook Noh ${ }^{3} \cdot{\text { Seong-Soo } \text { Roh }^{1}}^{1}$

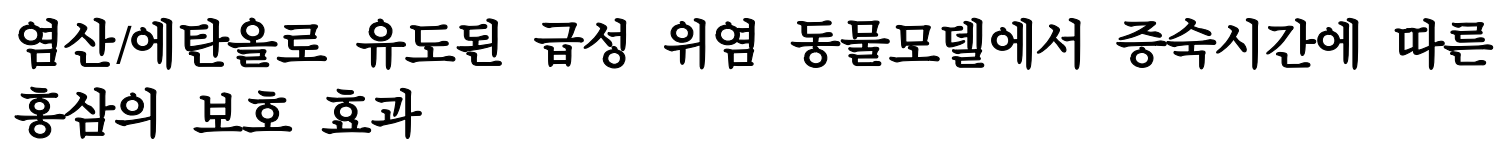

이주영 ${ }^{1} \cdot$ 권오준 $^{2} \cdot$ 노정숙 $^{3} \cdot$ 노성수 $^{1}$

Received: 4 June 2016 / Accepted: 19 September 2016 / Published Online: 31 December 2016

(C) The Korean Society for Applied Biological Chemistry 2016

\begin{abstract}
The objective of the present study was to evaluate the protective effect of red ginseng ( $R G$ ) according to steaming time on $150 \mathrm{mM} \mathrm{HCl} / 60 \%$ ethanol induced gastric ulcer models in mice. The sample was divided into 3 groups-G (dried ginseng), RG 4 (steamed $4 \mathrm{~h}$ and dried ginseng), RG 6 (steamed $6 \mathrm{~h}$ and dried ginseng), and determined through in vitro experiments, such as 1,1-diphenyl-2-picrylhydrazyl and 2,2'-azinobis-3-ethylbenzothiazoline-6-sulfonic acid radical scavenging activity, HPLC analysis, total polyphenol, and flavonoid contents. In vitro experiment results were depended on steaming hours. Based on the results, we chose two samples (G, RG 6) and conducted in vivo experiments. Mice were divided into 5 groups: Nor (normal group), Con (acute gastritis mice treated with distilled water), G (gastris induced by $\mathrm{HCl} /$ Ethanol treated with $100 \mathrm{mg} / \mathrm{kg} \mathrm{G}$ ), RG
\end{abstract}

Seong-Soo Roh $(\bowtie)$

E-mail: ddede@dhu.ac.kr

${ }^{1}$ College of Korean Medicine, Daegu Haany University, 64 Gil, 25 Suseongro, Suseong-gu, Daegu 42158, Republic of Korea

${ }^{2}$ Gyeongbuk Regional Industry Evaluation, Daegyeong Institute for Regional Program Evaluation, 27, Sampung-ro, Gyeongsan-si, Gyeongbuk 38542, Republic of Korea

${ }^{3}$ Department of Food Science \& Nutrition, Tongmyong University, 428, Sinseon-ro, Nam-gu, Busan 48520, Republic of Korea

This is an Open Access article distributed under the terms of the Creative Commons Attribution Non-Commercial License (http://creativecommons. org/licenses/by-nc/3.0/) which permits unrestricted non-commercial use, distribution, and reproduction in any medium, provided the original work is properly cited.
6 (gastris induced by $\mathrm{HCl} /$ ethanol treated with $100 \mathrm{mg} / \mathrm{kg} \mathrm{RG} \mathrm{6),}$ and $\mathrm{SC}$ (gastris induced by $\mathrm{HCl} /$ Ethanol treated with $10 \mathrm{mg} / \mathrm{kg}$ sucralfate). In our results revealed that RG 6 suppressed elevated reactive oxygen species, and inflammatory related makers, such as cyclooxygenase-2, inducible nitric oxide synthase, tumor necrosis factor alpha, and interleukin- 1 beta. In addition, gastric lesion area was improved. These results suggest that RG 6 protects the stomach by attenuating oxidative stress and inflammatory response under gastric ulcer conditions. Therefore, RG 6 should be a potential therapeutic agent for the treatment of acute gastric ulcer.

Keywords Anti-inflammation · Anti-oxidation · Gastritis · Red ginseng

\section{서 론}

위염은 위 점막에 생기는 염증성 질환을 통틀어 이르는 용어로, 한번 생긴 위염은 만성으로 발전하기 쉽다. 위벽은 4 개의 층으 로 이루어져 있는데, 첫 번째 층인 위 점막만 손상된 경우를 보 통 위염이라고 하고, 두 번째 층 이상이 손상되어 점막하층까 지 드러난 경우를 위궤양이라고 한다(Banks 1986). 인체의 생 명유지에 필요한 에너지를 생성하는 호흡과정에서 체내로 공급 된 산소 중 일부는 활성산소종(reactive oxygen species, ROS) 으로 전환된다(Droge 2001). 생체는 활성산소종으로부터 세포를 보호하기 위한 항산화 시스템을 가지고 있어 정상적인 상태에 서는 산화 작용이 해로운 영향을 주지 않지만 활성산소종이 과 잉 생산될 경우, 산화적 스트레스가 발생하며 이로 인해 체내 
항산화 체계의 균형이 깨져 여러 질환이 발병하는 것으로 알려 져 있다(Halliwell 등, 1995). ROS의 축적으로 인해 위 점막의 세포손상이 시작되며 염증반응의 전사인자인 inducible nitric oxide synthase (iNOS)와 cyclooxygenase-2 (COX-2)를 발현시 켜 염증반응을 일어나게 한다(Hogg 등, 1992; HernandezMunoz 등, 2000; Kojima 등, 2000; Guo 등, 2006; Shen과 Tergaonkar 2009). ROS의 형성으로 인한 산화적 스트레스는 생 체 내의 방어기작인 항산화 효소에 의하여 억제되지만 폴리페 놀 화합물과 비타민 $\mathrm{E}, \mathrm{C}$, 플라보노이드 등과 같은 식이 항산 화 성분의 섭취에 의해서도 효과적으로 방어될 수 있다(La Casa 등, 2000).

인삼(Panax ginseng C.A. Meyer)은 두릅나무과(Araliaceae)에 속한 인삼의 뿌리이다. 인삼의 주요 유효성분으로 saponin의 일 종인 ginsenoside가 있으며 이외에 acidic polysaccharide, panaxydol 등의 polyacetylene계 성분 및 여러 종의 아미노산 성분도 함유 하고 있다(Kim 등, 2007b). 인삼의 약리작용으로는 학습력 및 기억력 향상, 중추신경계의 흥분 및 억제 작용, 면역기능 증강, 혈액순환 개선, 항우울증, 항스트레스 및 항피로 작용 등이 있 다(KG와 TRI 1996; Park 등, 2007). 인삼은 1차 가공방법에 따라 수삼(생인삼), 백삼, 홍삼으로 구분한다(Lee 등, 2008). 수 삼은 가공 하지 않은 상태의 인삼을 말하며, 백삼은 4년근 이 상의 수삼을 원료로 하여 햇볕, 열풍 또는 기타 방법으로 익히 지 않고 말린 것을 말한다(Park 등, 2007). 홍삼(Red ginseng) 은 수삼을 증기로 쪄서 건조시킨 담황갈색 또는 담적갈색 인삼 을 말하며, 제조과정 중 일부 성분들의 함량이 증가하거나 화 학구조가 변환되어 새로운 saponin성분이 생성되기도 한다. 홍 삼은 prosapogenin (ginsenoside- $\mathrm{Rh} 2, \mathrm{Rh} 1, \mathrm{Rg} 2$ 및 $\mathrm{Rg} 3$ )성분 을 함유하고 있으며 백삼에 비해 분자량이 작은 다당체를 다량 함유하고 있다(Park 등, 2000; Kim 등, 2007a). 이러한 성분들 이 항혈전작용(Lee 등, 1998), 항암작용(Kim 등, 1999; Surh 등, 2000), 항산화작용(Choi 등, 2003; Joung 등, 2010) 등이 있다고 보고되고 있다. 이전연구에 따르면 홍삼의 증숙 시간에 따라 prosapogenin 성분의 함량이 높아지는 결과가 보고되어 있 다(Kim 등, 2012). 그러나 증숙 시간을 달리한 홍삼의 위염 보 호 효과에 대한 연구가 미비하다. 이에 본 연구에서는 증숙 시 간에 따른 홍삼의 항산화능 변화를 측정하고 급성 위염 동물 모델을 이용하여 산화적 스트레스 소거능, 웨스턴 분석, 조직학 적 관찰 등을 통해 홍삼의 위염 보호 효과를 평가하였다.

\section{재료 및 방법}

\section{실험재료}

시료제조에 사용된 약재는 경기도 여주시 장호원읍에서 재배된 6년근 수삼(Panax ginseng C.A. Meyer)으로 2013년 10월에 직 접 수매하여 사용하였다. 백삼 $(\mathrm{G})$ 은 절단하지 않고 잔뿌리가 떨 어지지 않도록 밀폐제습식 건조기(ACE Machinery, Seoul, Korea)를 사용하여 수분함량 $15 \%$ 미만으로 건조하였고, 홍삼 은 증숙과 무압식 스팀증숙기(ACE Machinery)를 사용하여 증 숙온도 $90{ }^{\circ} \mathrm{C}$ 에서 물로 4 시간(RG 4), 6시간(RG 6)씩 증숙한 후 건조기에서 건조하였다. 백삼과 증숙 홍삼 시료들의 추출은 분쇄기로 분쇄한 다음 시료 $5 \mathrm{~g}$ 에 증류수 $50 \mathrm{~mL}$ 를 넣고, 100
Table 1 Changes in ginsenoside compositions of ginseng by the steam processing

\begin{tabular}{|c|c|c|c|}
\hline \multirow{2}{*}{$\begin{array}{l}\text { Ginsenoside } \\
(\mathrm{mg} / \mathrm{g})\end{array}$} & \multicolumn{3}{|c|}{ Sample $^{1)}$} \\
\hline & G & RG 4 & RG 6 \\
\hline Rg1 & 0.470 & 0.559 & 0.470 \\
\hline $\operatorname{Re}$ & 0.259 & 0.277 & 0.251 \\
\hline $\mathrm{Rf}$ & 0.181 & 0.168 & 0.191 \\
\hline $\mathrm{Rb} 1$ & 0.662 & 1.330 & 1.357 \\
\hline $\operatorname{Rg} 2(s)$ & 0.028 & 0.288 & 0.049 \\
\hline $\mathrm{Rc}$ & 0.269 & 0.833 & 0.854 \\
\hline $\operatorname{Rg} 2(r)$ & 0.035 & 0.032 & 0.018 \\
\hline $\mathrm{Rb} 2$ & 0.174 & 0.469 & 0.444 \\
\hline Rb3 & 0.036 & 0.084 & 0.089 \\
\hline F1 & $\mathrm{N} / \mathrm{D}$ & 0.045 & 0.048 \\
\hline $\mathrm{Rd}$ & 0.055 & 0.102 & 0.132 \\
\hline $\operatorname{Rg} 6$ & $\mathrm{~N} / \mathrm{D}$ & $\mathrm{N} / \mathrm{D}$ & 0.053 \\
\hline $\mathrm{F} 4+\mathrm{Rk} 3$ & $\mathrm{~N} / \mathrm{D}$ & 0.010 & 0.044 \\
\hline $\mathrm{Rh} 4$ & $\mathrm{~N} / \mathrm{D}$ & 0.039 & 0.041 \\
\hline $\operatorname{Rg} 3(s)$ & 0.018 & 0.063 & 0.070 \\
\hline $\operatorname{Rg} 3(r)$ & $\mathrm{N} / \mathrm{D}$ & 0.018 & 0.026 \\
\hline $\mathrm{CK}$ & $\mathrm{N} / \mathrm{D}$ & $\mathrm{N} / \mathrm{D}$ & $\mathrm{N} / \mathrm{D}$ \\
\hline Rk1 & 0.012 & 0.051 & 0.099 \\
\hline $\operatorname{Rg} 5$ & $\mathrm{~N} / \mathrm{D}$ & 0.061 & 0.269 \\
\hline Total(mg) & 1.867 & 4.435 & 4.506 \\
\hline
\end{tabular}

${ }^{1)} \mathrm{G}$ : Dried Panacs ginseng without processing, RG 4: steamed $4 \mathrm{~h}$ and dried ginseng, RG 6: steamed $6 \mathrm{~h}$ and dried ginseng

${ }^{\circ} \mathrm{C}$ 에서 3 시간씩 2회 반복 추출하였다. Kimble-filtering flask에 funnel을 장착하고 여과지(Whatman No. 2, GE healthcare, Arlington Heights, IL, USA)를 사용하여 추출물을 여과한 뒤 여과액을 미리 항량된 용기에 넣어 $45 \sim 50{ }^{\circ} \mathrm{C}$ 의 수온에서 rotary vacuum evapo gastris or (JP/N-1000X, Sunileyela Co. Ltd, Gyeonggi, Korea)를 사용하여 감압농축 후 동결건조하고 $-20{ }^{\circ} \mathrm{C}$ 에 보관하여 사용하였다.

본 실험에 사용한 시료는 대전대학교 한의학과 본초학교실 서영배 교수님께 제공받아 사용하였고 성분분석을 수행하였다. 성분분석 결과는 $\mathrm{G}$ 는 총 사포닌 함량이 $1.867 \mathrm{mg}$ 을 보인 반면, $\mathrm{RG} \mathrm{4}$ 의 경우 $4.435 \mathrm{mg}$ 의 함량을 보였으며 $\mathrm{RG} 6$ 는 $4.506 \mathrm{mg}$ 의 함량을 보였으며 증숙 시간에 따라 성분의 함량이 증가하는 것을 확인 할 수 있었다(Table 1).

\section{실험 동물}

모든 실험은 대구한의대학교 동물실험 윤리위원회의 승인 (DHU2016-021)을 얻어 시행하였으며 동물관리 규정을 준수하 였다. ICR mice계의 6주령 수컷을 오리엔트(Gyeonggi, Korea) 에서 구입하여 1 주일 동안 실험실 환경에 적응시킨 후 실험에 사용하였다. 동물 사육실의 조건은 conventional system으로 온 도 $22 \pm 2{ }^{\circ} \mathrm{C}$, 습도 $50 \pm 5 \%$, 명암주기(light : dark cycle)는 12시 간 주기로 조절하였다. 사료는 고형사료(조단백질 $22.1 \%$ 이상, 조지방 $8.0 \%$ 이하, 조섬유 $5.0 \%$ 이하, 조회분 $8.0 \%$ 이하, 칼 슘 $0.6 \%$ 이상, 인 $0.4 \%$ 이상, 항생제 무첨가, Samyang corporation, Seoul, Korea)와 물을 충분히 공급하였다. 


\section{Total polyphenol 함량 측정}

페놀성 물질이 phosphomolybic acid와 반응하여 청색을 나타내 는 Folin-Denis 법(velioglu 1998)을 이용하여 측정하였다. 각 시료 $25 \mu \mathrm{L}(1 \mathrm{mg} / \mathrm{mL})$ 과 $10 \%$ Folin-Ciocalteau's phenol reagent $500 \mu \mathrm{L}$ 를 혼합하여 실온에서 5 분간 반응시킨다. 그 후 $10 \%$ sodium carbonate $500 \mu \mathrm{L}$ 를 더하여 $30{ }^{\circ} \mathrm{C}$ 에서 90 분 동안 반응 시킨 후 $725 \mathrm{~nm}$ 에서 흡광도(Multiscan spectrum, Thermo Scientific, Waltham, MA, USA)를 측정하였다. Total polyphenol 함량은 gallic acid (Sigma Aldrich, St Louis, MO, USA)를 표준물질 로 이와 같은 방법으로 측정하여 작성한 표준곡선으로부터 함 량을 구하였다.

\section{Total flavonoid 함량 측정}

Total flavonoid의 함량 측정은 Davis법을 변형한 방법(Lister 등, 1994)에 따라 측정하였다. 추출한 시료 $300 \mu \mathrm{L}$ 에 diethylene glycol $600 \mu \mathrm{L}$ 를 잘 섞어준 후, 이 혼합물에 $1 \mathrm{~N} \mathrm{NaOH} 6 \mu \mathrm{L}$ 를 가하여 $37^{\circ} \mathrm{C}$ 에서 1 시간 동안 방치한 후 $420 \mathrm{~nm}$ 에서 흡광 도를 측정하였다. 이때 Total flavonoid 함량은 naringin (Sigma Aldrich)을 이용하여 작성한 표준곡선으로부터 함량을 구하였다.

\section{DPPH radical scavenging activity}

Hatano 등(1989)의 방법으로 1,1-diphenyl-2-picrylhydrazyl (DPPH) radical 소거능 활성을 측정하였다. DPPH는 Sigma-Aldrich에서 구매하였고, 양성대조군으로는 L-ascorbic acid를 사용하였다. 각 시료를 농도별로 희석한 용액 $100 \mu \mathrm{L}$ 와 $0.2 \mathrm{mM} \mathrm{DPPH}$ 용액 $100 \mu \mathrm{L}$ 를 혼합하여 $37^{\circ} \mathrm{C}$ 에서 30 분간 암소 상태에서 반응시켰 다. 이 반응액을 사용하여 $540 \mathrm{~nm}$ 에서 흡광도를 사용하여 측정 한 후, 전자공여능은 식(a)에 따라 계산하여 산출하였다. 식(a) DPPH Radical scavenging activity $(\%)=\left\{\left(O D_{\text {control }}-O D_{\text {sample }}\right) /\right.$ $\left.O D_{\text {control }}\right\} \times 100, O D_{\text {control }}$ : 시료가 들어가지 않은 경우(대조군) 흡 광도, $O D_{\text {sample }}$ : 시료가 들어간 경우 흡광도.

\section{ABTS radical scavenging activity}

Martins 등(2014)의 방법으로 2,2'-azinobis-3-ethyl-benzothiazoline6-sulfonic acid (ABTS) radical 소거능 활성을 이용하여 항산화 효과를 측정하였다. 실험에 사용된 $\mathrm{ABTS}$ 와 potassium persulfate는 Sigma-Aldrich에서 구매하였고, 양성대조군으로 Lascorbic acid를 사용하였다. $7 \mathrm{mM}$ ABTS 용액과 $2.4 \mathrm{mM}$ 의 potassium persulfate을 혼합하여 실온의 암소 상태에서 약 16시 간이상 방치하여 $\mathrm{ABTS}^{+}$을 형성시킨 후 $734 \mathrm{~nm}$ 에서 흡광도 값 이 $0.70 \pm 0.02$ 이 되게 absolute ethanol로 희석하였다. 희석된 용 액 $900 \mu \mathrm{L}$ 에 시료 $100 \mu \mathrm{L}$ 를 가하여 1 분 동안 방치한 후 흡광 도를 측정하였다. 흡광도는 식(b)에 따라 계산하여 산출하였다. 식(b) ABTS Radical scavenging activity $(\%)=\left\{\left(O D_{\text {control }}-O D_{\text {sample }}\right) /\right.$ $\left.O D_{\text {control }}\right\} \times 100, O D_{\text {control }}$ : 시료가 들어가지 않은 경우(대조군) 흡 광도, $O D_{\text {sample: }}$ 시료가 들어간 경우 흡광도.

\section{급성 위염 유발 동물 실험}

실험동물은 군당 6 마리씩 5그룹으로 나누어 실험을 진행하였다. 급성 위염 유발 전 24시간 동안 절식하였으며 물은 제공하였다. 실험 당일, 정상군(Nor)에는 아무런 처치를 하지 않았으며, 대 조군(Con)에는 증류수를 경구투여하였고, 양성대조군(SC)에는 sucralfate (Sigma Aldrich)를 $10 \mathrm{mg} / \mathrm{kg}$ body weight의 농도로 경구투여 하였다. $\mathrm{G}$ 과 $\mathrm{RG}$ 6는 각각 $100 \mathrm{mg} / \mathrm{kg}$ body weight 로 경구투여 하였다. 투여 1시간 후 $150 \mathrm{mM} \mathrm{HCl}$ 과 $60 \%$ ethanol을 섞은 용액을 $0.5 \mathrm{~mL}$ 경구투여 하였고, 1 시간 후 isoflurane (Sigma Aldrich)으로 흡입 마취 후 개복하여 심장에 서 채혈하고 위 조직을 적출하였다.

\section{위 점막 손상도 측정}

적출한 위 조직을 핀으로 고정한 다음, 광학 디지털 카메라 (DSC-HX50V, Sony, Tokyo, Japan)를 이용하여 촬영하였다. 손 상된 위점막 측정은 I-Solution lite (Innerview Co., Gyeonggi, Korea) 프로그램을 이용하여 실제 손상 부위의 면적을 측정한 후, 위 전체 면적과 비교하여 정상군에 대한 손상 비율로 표시 하였다.

\section{혈액의 산화적 스트레스 바이오마커 측정}

심장에서 채혈한 혈액을 $4,000 \mathrm{rpm}, 10$ 분 동안 원심 분리하여 혈청을 얻었다. ROS 측정은 Ali 등(1992)의 방법을 이용하여 시행하였다. 혈청과 $25 \mathrm{mM} \mathrm{2',7'-dichlorofluorescein} \mathrm{diacetate}$ (Molecular Probes, Eugene, OR, USA)를 혼합한 후, 형광 광 도계를 이용하여 0 분부터 매 5 분씩 35 분간 emission 파장 530 $\mathrm{nm}$ 와 excitation 파장 $485 \mathrm{~nm}$ 를 이용하여 30 분간 측정한 산출 값을 계산하였다. $\mathrm{ONOO}^{-}$는 Kooy 등(1994)의 연구를 이용하여 측정하였다. 각 샘플을 $\mathrm{pH} 7.4$ rhodamine buffer와 $5 \mathrm{mM}$ $\mathrm{DHR} 123$ 과 섞은 후 5 분간 $37^{\circ} \mathrm{C}$ 에서 흔들어 준 후 5 분씩 35 분 간 emission 파장 $535 \mathrm{~nm}$ 와 excitation 파장 $480 \mathrm{~nm}$ 를 이용하 여 30 분간 측정한 산출 값을 계산하였다.

\section{위 조직 western blotting}

위 조직의 세포질을 얻기 위해 $100 \mathrm{mM}$ 2-amino-2-hydroxymethyl-propane-1,3-diol (Tris)-HCl (pH 7.4), $5 \mathrm{mM}$ Tris-HCl ( $\mathrm{pH}$ 7.5), $2 \mathrm{mM} \mathrm{MgCl}_{2}, 15 \mathrm{mM} \mathrm{CaCl}, 1.5 \mathrm{M}$ sucrose, $0.1 \mathrm{M}$ dithiothreito (DTT), protease inhibitor cocktail을 첨가한 buffer $\mathrm{A}$ 를 넣고 tissue grinder (BioSpec Product, Bartlesville, Oklahoma, USA)로 분쇄한 후 $10 \% \mathrm{NP}-40$ 용액을 첨가하였다. 아이스 위 에서 20 분간 정치시킨 후 $12,000 \mathrm{rpm}$ 으로 2 분간 원심분리 $\left(12,000 \mathrm{rpm}, 20 \mathrm{~min}, 4^{\circ} \mathrm{C}\right)$ 하여 세포질을 포함하고 있는 상층액 을 분리하였다. 핵을 얻기 위해 $10 \% \mathrm{NP}-40$ 가 더해진 buffer $\mathrm{A}$ 에 두 번 헹구고 $100 \mu \mathrm{L}$ 의 buffer C $(50 \mathrm{mM}$ 2-[4-(2-hydroxyethyl)-1-piperazyl] ethanesulfonic acid ( $\mathrm{pH} 7.9), 50 \mathrm{mM} \mathrm{KCl}$, $0.3 \mathrm{mM} \mathrm{NaCl}, 0.1 \mathrm{mM}$ EDTA, $1 \mathrm{mM}$ DTT, $0.1 \mathrm{mM}$ PMSF, $10 \%$ glycerol)를 첨가해 재부유 시킨 뒤 10 분마다 vortex을 3 번 하였다. $4{ }^{\circ} \mathrm{C}$ 에서 $12,000 \mathrm{rpm}$ 으로 10 분간 원심분리한 후 핵 을 포함하고 있는 상층액을 얻어 $-80{ }^{\circ} \mathrm{C}$ 에서 냉동 보관하였다. 위 조직의 세포질의 iNOS, COX-2, tumor necrosis factor alpha (TNF)- $\alpha$, interleukin (IL)- $1 \beta, \beta$-actin 단백질의 발현을 측정하기 위하여 $10 \mu \mathrm{g}$ 의 단백질을 $8 \sim 15 \%$ SDS-polyacrylamide gel을 이용하여 전기영동 후, acrylamide gel을 nitrocellulose membrane 으로 이동시켰다. 준비된 membrane에 각각의 1차 antibody를 처리하여 $4{ }^{\circ} \mathrm{C}$ 에서 overnight 시킨 다음 PBS-T로 6분마다 5회 세척하고, 각각 처리된 1 차 항체에 사용되는 2 차 항체(PBS-T로 $1: 3000$ 로 희석해서 사용)를 사용하여 상온에서 1시간 반응시킨 
후, PBS-T로 6분마다 5회 세척하였다. 그리고 enhanced chemiluminescence (GE Healthcare, Arlington Heights, IL, USA)에 노출시킨 후, Sensi-Q2000 Chemidoc (Lugen Sci Co. Ltd., Seoul, Korea)에 감광시켜 단백질 발현을 확인한 후, 해당 band를 ATTO Densitograph Software (ATTO Corporation, Tokyo, Japan)를 사용하여 정량하였다.

\section{통계분석}

In vitro의 수치는 평균과 표준오차로, in vivo의 수치는 평균과 표준편차로 표시하였으며, SPSS (Version 22.0, IBM, Armonk, NY, USA)을 사용하여 one-way analysis of variance (ANOVA) test를 실시한 후 Tukey Multiple Comparison test로 사후검증 을 실시하여 군 간의 유의성을 측정하였다. 각 군의 평균 차이 에 대한 통계적 유의성을 $5 \%$ 수준에서 검증하였다. Student's paired t-test을 사용하여 백삼과 다른 군간의 통계적 유의성을 측정하였다 $(p<0.05)$.

\section{결과 및 고찰}

\section{Total polyphenol 및 total flavonoid 함량 측정 결과}

백삼과 홍삼에는 salicylic acid, cinnamic acid, vanillic acid, $p$-coumaric acid, ferulic acid, caffeic acid, procatechuic acid, esculetin, quercetin 및 maltol 등의 페놀성 화합물들이 함유되어 있다고 보고되어져있다(Hwang 등, 2006). Noh 등(2005)은 양 배추의 총 페놀성 화합물의 함량은 추출 용매나 시간 등의 영 향을 받는다 하였으며, Holasova 등(2002)은 phenol 함량이 높 을수록 항산화 활성이 증가한다고 보고되었다.

Total polyphenol 함량을 측정한 결과, $\mathrm{RG}$ 6는 $\mathrm{G}$ 와 비교하 여 1.75배 증가하였으며 Total flavonoid 함량 또한 $\mathrm{G}$ 와 비교하 여 $\mathrm{RG}$ 6에서 1.75 배 증가하였다(Table 2). 증숙 시간이 증가할 수록 총 Total polyphenol 및 Total flavonoid 함량이 늘어나는 것을 확인할 수 있었다.

\section{DPPH 및 ABTS radical 소거 활성 측정 결과}

$\mathrm{DPPH}$ 및 $\mathrm{ABTS}$ radical 소거능을 이용하여 항산화 효능을 측 정하였다. $\mathrm{DPPH}$ radical 소거능 측정 결과, $\mathrm{G}$ 의 $\mathrm{IC}_{50}$ 값은 $1698.02 \pm 199.07 \mu \mathrm{g} / \mathrm{mL}$ 을 나타낸 반면 RG 6는 $501.87 \pm 12.95$ $\mu \mathrm{g} / \mathrm{mL}$ 의 값을 나타내었다. ABTS radical 소거능 측정 결과, $\mathrm{G}$ 의 $\mathrm{IC}_{50}$ 값은 $727.14 \pm 37.37 \mu \mathrm{g} / \mathrm{mL}$ 을 나타내었고 $\mathrm{RG}$ 6는 611.42 $\pm 32.34 \mu \mathrm{g} / \mathrm{mL}$ 의 $\mathrm{IC}_{50}$ 값을 나타내었다. ABTS radical 소거능 또 한 앞서 살펴본 $\mathrm{DPPH}$ radical 소거능과 동일한 경향을 보였다 (Table 3).

시료의 증숙 시간이 증가함에 따라 DPPH 및 ABTS radical 소거 활성이 증가하는 경향을 보였으며, Table 2의 Total polyphenol 함량 측정과 일치하는 결과를 보였다. 또한 홍삼을 증숙과 건조할 때 가해지는 열에 의해 홍삼의 saponin성분이 변 화하는데, $\mathrm{Nam}(2005)$ 의 증숙 시간별 ginsenoside의 함량이 증 가한다는 연구와 일치하는 결과를 보였다(Table 1). 홍삼 제조 시 갈색화 반응에 의해 생성된 갈변 물질(Nam 2005), phenol (Holasova 등, 2002)과 ginsenoside 함량(Choi 등, 2003)에 따 라 높은 항산화 활성을 가진다는 연구 결과가 보고되어 있다.
Table 2 Total polyphenol and total flavonoid contents of ginseng and red ginseng by steaming-drying processing

\begin{tabular}{ccc}
\hline Sample & Total polyphenol $(\mathrm{mg} / \mathrm{g})$ & Total flavonoid $(\mathrm{mg} / \mathrm{g})$ \\
\hline $\mathrm{G}^{2)}$ & $3.12 \pm 0.01^{1) \mathrm{c}}$ & $1.41 \pm 0.05^{\mathrm{c}}$ \\
RG 4 & $4.23 \pm 0.08^{\mathrm{b}}$ & $1.73 \pm 0.08^{\mathrm{b}}$ \\
RG 6 & $5.46 \pm 0.04^{\mathrm{a}}$ & $2.48 \pm 0.01^{\mathrm{a}}$ \\
\hline
\end{tabular}

${ }^{1)}$ All values are mean $\pm \mathrm{SE}$ of three replications

${ }^{2)} \mathrm{G}$ : Dried Panacs ginseng without processing, RG 4: steamed $4 \mathrm{~h}$ and dried ginseng, RG 6: steamed $6 \mathrm{~h}$ and dried ginseng

${ }^{\mathrm{a} \sim c}$ Results were assessed by one-way ANOVA followed by Tukey Multiple Comparison test $(p<0.05)$

Table 3 DPPH and ABTS radical scavenging activity of ginseng and red ginseng by steaming-drying processing

\begin{tabular}{ccc}
\hline Sample & $\begin{array}{c}\mathrm{IC}_{50} \text { values of DPPH } \\
\text { radical scavenging } \\
\text { activity }(\mathrm{g} / \mathrm{mL})\end{array}$ & $\begin{array}{c}\mathrm{IC}_{50} \text { values of ABTS } \\
\text { radical scavenging } \\
\text { activity }(\mathrm{g} / \mathrm{mL})\end{array}$ \\
\hline L-ascorbic acid & $0.99 \pm 0.01^{1)}$ & $3.20 \pm 0.1$ \\
$\mathrm{G}^{2}$ & $1698.02 \pm 199.07^{\mathrm{a}}$ & $727.14 \pm 37.37^{\mathrm{a}}$ \\
$\mathrm{RG} \mathrm{4}$ & $792.49 \pm 18.14^{\mathrm{b}}$ & $624.12 \pm 147.88^{\mathrm{a}}$ \\
RG 6 & $501.87 \pm 12.95^{\mathrm{b}}$ & $611.42 \pm 32.34^{\mathrm{a}}$ \\
\hline
\end{tabular}

${ }^{1)}$ All values are mean $\pm \mathrm{SE}$ of three replications

${ }^{2)} \mathrm{G}$ : Dried Panacs ginseng without processing, RG 4 : steamed $4 \mathrm{~h}$ and dried ginseng, RG 6: steamed $6 \mathrm{~h}$ and dried ginseng

${ }^{a-b}$ Results were assessed by one-way ANOVA followed by Tukey Multiple Comparison test $(p<0.05)$

$\mathrm{IC}_{50}$ : The half maximal inhibitory concentration

이러한 연구결과를 바탕으로 RG 6에서 가장 높은 항산화 활성 을 나타낸 것으로 사료된다.

\section{위 점막 보호 효과}

위 점막을 육안으로 관찰한 결과, 정상군에서는 점막 손상이 발 견되지 않았으나 대조군은 $150 \mathrm{mM} \mathrm{HCl} / 60 \%$ ethanol에 의해 손상을 받아 출혈 및 발적이 뚜렷이 관찰되었다. 반면 양성대 조군 $\mathrm{SC}$ 군과 $\mathrm{RG}$ 6군에서는 출혈성 점막손상이 현저히 감소되

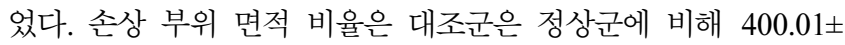
54.29 (AU)로 높게 나타났다. G군은 203.73 \pm 42.27 (AU), RG 6군은 60.81 \pm 8.39 (AU)로 나타났으며, 양성대조군 $\mathrm{SC}$ 군은 $73.76 \pm 4.47(\mathrm{AU})$ 의 손상도를 보였다. $\mathrm{RG}$ 6군은 $\mathrm{G}$ 군에 비해 유의성 있는 개선효과를 보였다(Fig. 1).

\section{산화적 스트레스 바이오 마커 변화}

Olaleye 등(2007)의 연구에 따르면 알코올에 의한 위염을 일으 키는 중요한 인자로 산화적 손상이 작용한다고 보고되어 있다. $\mathrm{ROS}$ 가 체내에 축적되어 정상적으로 소거되지 않았을 때 세포 를 산화적 스트레스 상태에 이르게 하며, 과도한 산화적 스트 레스 상태에서 생성된 peroxynitrite $\left(\mathrm{ONOO}^{-}\right)$는 protein과 DNA 등과 반응하여 세포의 손상을 야기한다. 또한 염증반응 및 여러 만성질환 발생에 관여한다(Radi 등, 1991; Cowan과 Storey 2003; Ebadi와 Sharma 2003). 이러한 염증반응 및 조직 손상은 항산화 기능을 통하여 치료하고 조직을 보호하는 역할 을 한다고 보고되어 있다(Kwiecieñ 등, 2002; Kahraman 등, 2003). 
(A)

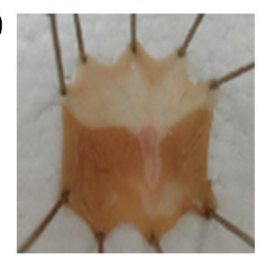

(C)

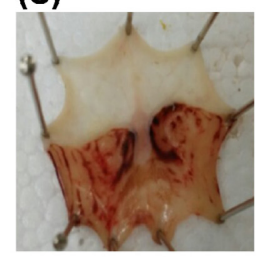

(B)

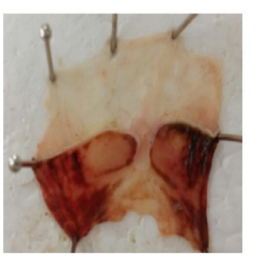

(E)
(D)

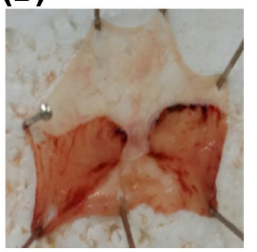

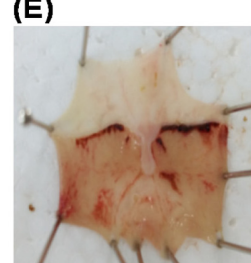

(F)

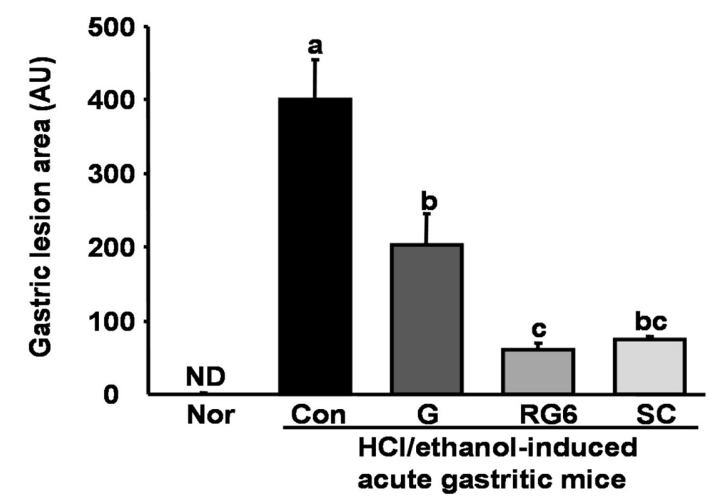

Fig. 1 Gross appearance of stomach tissues in $\mathrm{HCl} /$ ethanol-induced acute gastritic mice. All values are mean $\pm \mathrm{SD}(\mathrm{n}=6)$. (A) Nor, normal mice, (B) Con, $\mathrm{HCl} /$ ethanol-induced acute gastritic mice with the administration of distilled water, $(\mathrm{C}) \mathrm{G}, \mathrm{HCl} /$ ethanol-induced acute gastritic mice with the administration of $100 \mathrm{mg} / \mathrm{kg}$ ginseng, (D) RG 6, HCl/ethanol-induced acute gastritic mice with the administration of $100 \mathrm{mg} / \mathrm{kg}$ red ginseng by steamed $6 \mathrm{~h},(\mathrm{E}) \mathrm{SC}, \mathrm{HCl} /$ ethanol-induced acute gastritic mice with the administration of $10 \mathrm{mg} / \mathrm{kg}$ sucralfate, (F) gastric mucosal injury area. ND: Not detected. Different letters show a significantly difference at $p<0.05$ as determined by one-way ANOVA followed by Turkey multiple comparison test.
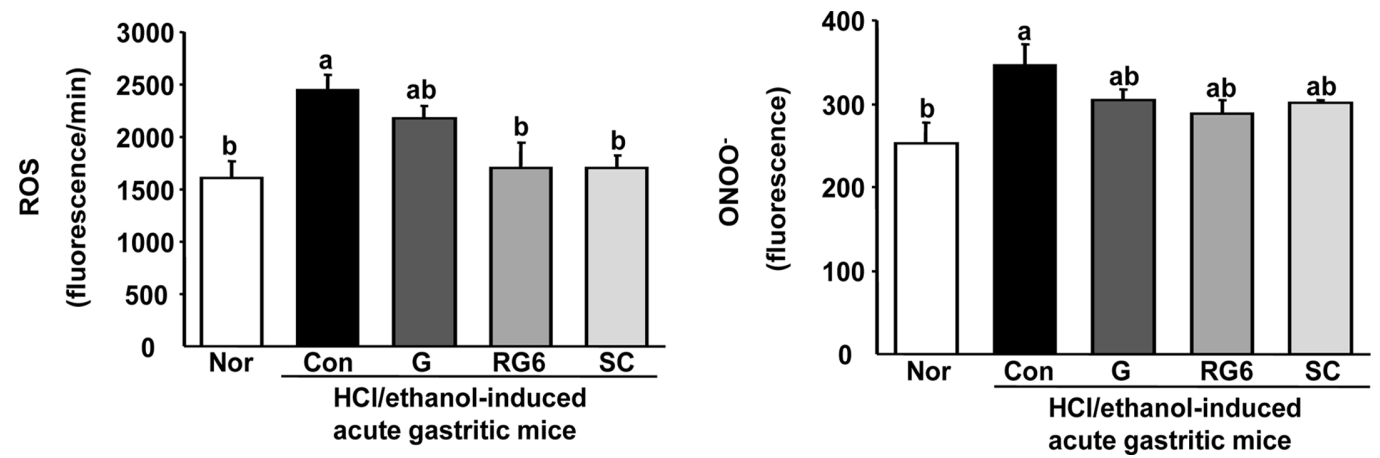

Fig. 2 Effect of red ginseng on oxidative stress biomarker level of serum in $\mathrm{HCl} /$ ethanol-induced acute gastritic mice. All values are mean $\pm \mathrm{SD}$ ( $\mathrm{n}=6$ ). Nor, normal mice; Con, HCl/ethanol-induced acute gastritic mice with the administration of distilled water; G, HCl/ethanol-induced acute gastritic mice with the administration of $100 \mathrm{mg} / \mathrm{kg}$ ginseng; $\mathrm{RG} 6, \mathrm{HCl} /$ ethanol-induced acute gastritic mice with the administration of $100 \mathrm{mg} / \mathrm{kg}$ red ginseng by steamed $6 \mathrm{~h}$; SC, HCl/ethanol-induced acute gastritic mice with the administration of $10 \mathrm{mg} / \mathrm{kg}$ sucralfate. Different letters show a significantly difference at $p<0.05$ as determined by one-way ANOVA followed by Turkey multiple comparison test.

혈청을 이용하여 ROS 측정 실험 결과, 대조군(2441.7 \pm 155.9 fluorescence/min)은 정상군(1608.9 \pm 57.1 fluorescence/min)에 비 해 유의성 있게 증가하였다. 또한 양성대조군 $\mathrm{SC}$ 투여군(1697.8 \pm 131.7 fluorescence/min)과 RG 6 군 $(1705.3 \pm 234.7$ fluorescence/ $\min$ )은 대조군에 비해 유의성 있는 감소를 보였다. $\mathrm{ONOO}^{-}$측 정 결과, 대조군(346.5 \pm 24.8 fluorescence/min)은 정상군(252.3 \pm 25.6 fluorescence $/ \mathrm{min}$ )에 비해 유의성 있게 증가하였고 $\mathrm{SC}$ 군 (301 \pm 2.9 fluorescence/min)과 RG 6 투여군(287.8 \pm 16.3 fluorescence/ 

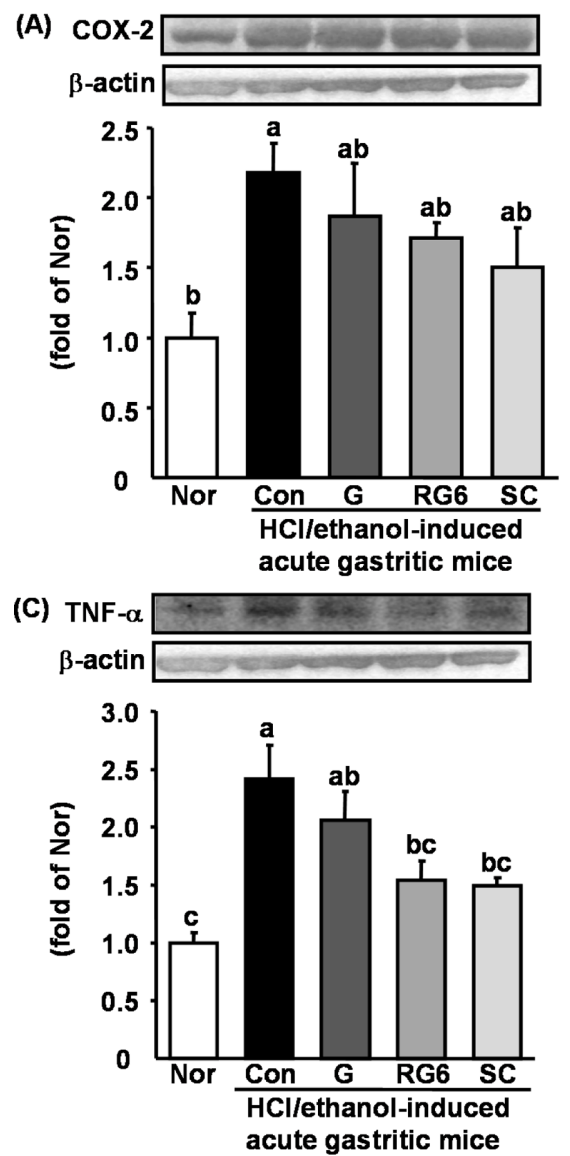

(B)
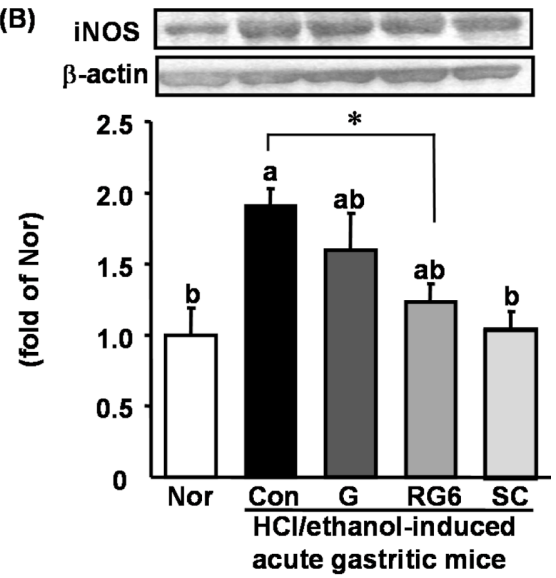

(D)
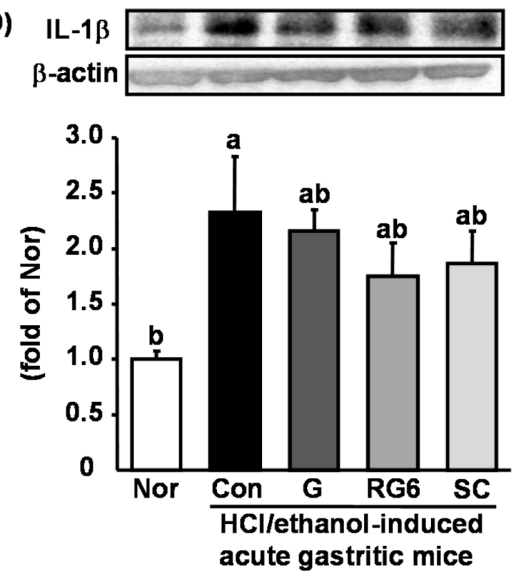

Fig. 3 Effect of black ginseng on inflammatory factors of stomach tissues in $\mathrm{HCl} /$ ethanol-induced acute gastritic mice. All values are mean $\pm \mathrm{SD}$ ( $\mathrm{n}=6$ ). Nor, normal mice; Con, $\mathrm{HCl} /$ ethanol-induced acute gastritic mice with the administration of distilled water; $\mathrm{G}$, $\mathrm{HCl} / \mathrm{ethanol-induced} \mathrm{acute} \mathrm{gastritic} \mathrm{mice}$ with the administration of $100 \mathrm{mg} / \mathrm{kg}$ ginseng; RG $6, \mathrm{HCl} /$ ethanol-induced acute gastritic mice with the administration of $100 \mathrm{mg} / \mathrm{kg}$ red ginseng by steamed $6 \mathrm{~h}$; SC, HCl/ethanol-induced acute gastritic mice with the administration of $10 \mathrm{mg} / \mathrm{kg}$ sucralfate. ${ }^{\mathrm{a} \sim \mathrm{c}}$ Different letters show a significantly difference at $p<0.05$ as determined by one-way ANOVA followed by Turkey multiple comparison test. *The Student's paired t-test was carried out to compare with the Con group $(p<0.05)$.

$\min )$ 은 대조군에 비해 감소하는 경향을 보였다. Alrashdi 등 (2012)의 연구에 따르면 $\mathrm{HCl} / \mathrm{ethanol} \mathrm{동물모델에서} \mathrm{항산화} \mathrm{관련}$ 인자의 증가와 산화적 스트레스를 감소시켜 위 점막 손상을 보 호한다고 보고되어져있다. 본 연구에서 $\mathrm{RG}$ 6가 ROS와 $\mathrm{ONOO}^{-}$발현을 억제하므로 산화적 스트레스를 방어하는 효과 가 있으며, 높은 항산화 활성이 나타나므로 위 점막 손상을 보 호하는 것으로 사료된다(Fig. 2).

\section{위 조직의 염중성 사이토카인 발현}

염증반응은 조직 손상을 통해 일어나게 되며 면역관련 세포들 이 염증매개물질들을 분비하여 발생한다(Owens와 Grisham 1993; Finotto 등, 1994; Pravda 2011). COX-2는 미생물의 감 염이나 여러 요인의 스트레스에 반응한 대식세포에서 발현된다 (Kim 등, 2004). iNOS는 세포내 존재하지 않으나 lipopolysaccharide, 염증성 사이토카인 등의 자극이 있을 때 발현되며, ROS의 일종인 $\mathrm{NO}$ 를 생성한다(Weisz 등, 1996). NO는 체내에 서 항균과 종양제거에 있어서 중요한 역할을 하지만, 염증시 $\mathrm{iNOS}$ 에 의해 생성된 생체 내 고농도의 $\mathrm{NO}$ 는 염증반응을 촉진,
심화시키는 것으로 알려져 있다(Cheon 등, 2009). 대조군의 위 조직에서 western blot을 실시하여 염증인자인 COX-2와 iNOS 그리고 염증성 사이토카인인 TNF- $\alpha$ 와 IL- $1 \beta$ 의 발현을 확인한 결과, 대조군과 비교하였을 때 G와 RG 6 투여군에서 $\mathrm{COX}-2$ 와 IL- $1 \beta$ 가 감소하는 경향을 보였다. 그러나 $\mathrm{TNF}-\alpha$ 와 $\mathrm{iNOS}$ 의 경우, 대조군에 비해 RG 6 투여군은 유의성 있는 감소를 나타냈다. 이상의 결과를 종합해볼 때 RG 6가 염증성 사이토 카인의 발현을 억제하므로 항염증 효과가 있는 것으로 사료된 다(Fig. 3).

\section{초 록}

본 연구에서는 $150 \mathrm{mM} \mathrm{HCl} / 60 \%$ ethanol로 급성 위염을 유발 한 마우스에서 증숙 시간에 따른 홍삼의 위염 보효 효과에 대 해 살펴보고자 하였다. 백삼과 홍삼의 증숙 시간에 따른 성분 을 분석한 결과 사포닌, total polyphenol과 total flavonoid의 총 함량이 증숙 시간에 따라 증가하였고 6 시간 증숙한 홍삼에 
서 가장 높은 함량을 보였다. 또한 1,1-diphenyl-2-picrylhydrazyl 와 2,2'-azinobis-3-ethyl-benzothiazoline-6-sulfonic acid radical 소거능 실험을 통해 항산화 활성을 측정한 결과 $\mathrm{RG} 6$ 에서 가 장 높은 활성을 나타냈다. In vitro 실험 결과를 바탕으로 시료 를 선택하였고 in vivo 실험을 진행하였다. 급성 위염 마우스 모델에 백삼과 6시간 증숙한 홍삼을 투여하였을 때, RG 6에서 위 점막 손상의 개선을 육안적으로 확인할 수 있었으며, 혈액 에서 측정한 $\operatorname{ROS}$ 수치도 대조군에 비해 유의적인 감소를 보였 다. 또한 염증성 사이토카인을 확인한 결과 대조군에 비해 RG 6 에서 감소하는 경향을 보였다. 이러한 결과들을 종합해 볼 때 증숙 시간에 따른 홍삼은 급성 위염 유발 마우스 모델에서 위 염 보호 효과가 있는 것으로 사료된다.

Keywords 위염 · 항산화 · 항염증 · 홍삼

\section{References}

Ali SF, LeBel CP, Bondy SC (1992) Reactive oxygen species formation as a biomarker of methylmercury and trimethyltin neurotoxicity. Neurotoxicology 13: 637-648

Alrashdi AS, Salama SM, Alkiyumi SS, Abdulla MA, Hadi AH, Abdelwahab SI, Taha MM, Hussiani J, Asykin N (2012) Mechanisms of Gastroprotective Effects of Ethanolic Leaf Extract of Jasminum sambac against $\mathrm{HCl} /$ Ethanol-Induced Gastric Mucosal Injury in Rats. Evid Based Complement Alternat Med. doi:10.1155/2012/786426

Banks WJ (1986) Applied veterinary histology (2nd ed.), William \& Wilkins, Baltimore

Cheon YP, Mollah ML, Park CH, Hong JH, Lee GD, Song JC, Kim KS (2009) Bulnesia sarmienti aqueous extract inhibits inflammation in LPSstimulated RAW 264.7 cells. J Life Sci 19: 479-485

Choi M, Shin GJ, Choi GP, Do JH, Kim JD (2003) Synergistic effects of extracts from Korean red ginseng, Saururus chinensis (Lour.) Baill. and Rubus coreanus Miq. on antioxidative activities in rats. Korean J Medicinal Crop Sci 14: 27-30

Cowan KJ, Storey KB (2003) Mitogen-activated protein kinases: new signaling pathways functioning in cellular responses to environmental stress. J Exp Biol 206: 1107-1115

Droge W (2001) Free radicals in the physiological control of cell function Physiol Rev 82: 47-95

Ebadi M, Sharma SK (2003) Peroxynitrite and mitochondrial dysfunction in the pathogenesis of Parkinson's disease. Antioxid Redox Signal 5: 319 335

Finotto S, Ohno I, Marshall JS, Gauldie J, Denburg JA, Dolovich J, Clark DA, Jordana M (1994) TNF-alpha production by eosinophiles in upper airways inflammation (nasal polyposis). J Immunol 153: 2278-2289

Guo JS, Cho CH, Wang JY, Koo MW (2006) Differential effects of selective and non-selective inhibition of nitric oxide synthase on the expression and activity of cyclooxygenase-2 during gastric ulcer healing. Eur $\mathrm{J}$ Pharmacol 536: 301-308

Halliwell B, Aeschbach R, Lõliger J, Aruoma OI (1995) The characterization of antioxidants. Food Chem Toxico 33: 601-617

Hatano T, Edamatsu R, Hiramatsu M, Mori A, Fujita Y, Yasuhara T, Yoshida T, Okuda T (1989) Effects of the interaction of tannins with co-existing substances. VI. Effects if tannins and related polyphenols on superoxide anion radical, and 1,1-diphenyl-2-picrylhydrazyl radical. Chem Pharm Bull 37: 2016-2021

Hernandez-Munoz R, Montiel-Ruiz C, Vazquez-Martinez O (2000) Gastric mucosal cell proliferation in ethanol-induced chronic mucosal injury is related to oxidative stress and lipid peroxidation in rats. Lab Invest 80 : $1161-1169$
Hogg N, Darley-Usmar VM, Wilson MT, Moncada S (1992) Production of hydroxyl radicals from the simultaneous generation of superoxide and nitric oxide. Biochem J 15: 419-424

Holasova M, Fiedlerova V, Smrcinova H, Orsak M, Lachman J, Vavreinova S (2002) Buckwheat the source of antioxidant activity in functional foods. Food Res Int. 35: 207-211

Hwang EY, Kong YH, Lee YC, Kim YC, Yoo KM, Jo YO, Choi SY (2006) Comparison of phenolic compounds contents between white and red ginseng and their inhibitory effect on melanin biosynthesis. J Ginseng Res 30: 82-87

Joung EM, Kim HY, Hwng IG, Jeong JH, Yu KW, Lee JS, Jeong HS (2010) Chgnges of antioxidant activties on clutured ginseng with mushroom mycelia during cultivaiton. J Korean Soc Food Sci Nutr 39: 1346-1352

Kahraman A, Erkasap N, Koken T, Serteser M, Aktepe F, Erkasap S (2003) The antioxidative and antihistaminic properties of quercetin in ethanolinduced gastric lesions. Toxicology 183: 133-142

KG and TRI (1996) New Korean Ginseng. Korea Ginseng \& Tabacco Research Institute, Daejeon

Kim DK, Baik MY, Kim HK, Hahm YT, Kim BY (2012) Manufacture of the Red Ginseng Vinegar Fermented with Red Ginseng Concentrate and Rice Wine, and its Quality Evaluation. Korean J Food.Sci Technol 44: 179-184

Kim JY, Jung KS, Jeong HG (2004) Suppressive effects of the kahweol and cafestol on cyclooxygenase-2 expression in macrophages. FEBS letters 569: 321-326

Kim KY, Shin JK, Lee SW, Yoon SR, Chung HS, Jeong YJ, Choi MS, Lee CM, Moon KD, Kwon JH (2007a) Quality and Functional Properties of Red Ginseng Prepared with Different Steaming Time and Drying Methods. Korean J Food Sci Techinol 39: 494-499

Kim SE, Lee YH, Park JH, Lee SK (1999) Ginsenoside Rs3, a new diol-type ginseng saponin, selectively elevates protein levels of p53 and p21WAF1 leading to induction of apoptosis in SK-HEP-1 cells. Anticancer Res 19: 487-491

Kim YS, Kim SN, Ha YW, Shin H, Son SH, Wu SJ (2007b) Simultaneous quantification of Ginsenosides in Panax ginseng C.A. Meyer (Korean red ginseng) by HPLC-ELSD and its application to quality control. J Pharm Biomed Anal 45: 164-170

Kojima M, Morisaki T, Izuhara K, Uchiyama Y, Matsunari Y, Katano M, Tanaka M (2000) Lipopolysaccharide increases cyclo-oxygenase-2 expression in a colon carcinoma cell line through nuclear factor- $\mathrm{kB}$ activation. Oncogene 19: 1225-1231

Kooy NW, Royall JA, Ischiropoulos H, Beckman JS (1994) Peroxynitritemediated oxidation of dihydrohodamine 123. Free Radic Biol Med 16: $149-156$

Kwiecieñ S, Brzozowski T, Konturek SJ (2002) Effects of reactive oxygen species action on gastric mucosa in various models of mucosal injury. $\mathrm{J}$ Physiol Pharmacol 53: 39-50

La Casa C, Villegas I, Alarcon de la Lastra C, Motilva V, Martin Calero MJ (2000) Evidence for protective and antioxidant properties of rutin, a natural flavone, against ethanol induced gastric lesions. J Ethnopharmacol 71: 45-53

Lee HK, Jung KY, Kim DS, Oh SR, Lee IS, Lee JJ, Park JD, Kim SI (1998) Platelet activating factor antagonist activity of ginsenoside. Biol Pharm Bull 21: 79-80

Lee MJ, Kim EH, Rhee DK (2008) Effects of Panax ginseng on stress. J Ginseng Res 32: 8-14

Lister CE, Lancaster JE, Sutton KH, Walker JRL (1994) Developmental changes in the concentration and composition of flavonoids in skin of a red and a green apple cultivar. J Science Food and Agric 64: 155-161

Martins JLR, Rodrigues ORL, da Silva DM, Galdino PM, de Palula JR, Romao W, Romao W, da Costa HB, Vaz BG, Ghedini PC, Costa EA (2014) Mechanisms involved in the gastro protective activity of Celtis iguanaea (Jacq.) Sargent on gastric lesions in mice. J Ethnopharmacol 155: 1616-1624

Nam KY (2005) The comparative understanding between red ginseng and 
white ginsengs, processed ginsengs (Panax ginseng CA Meyer). J Ginseng Res 29: 1-18

Noh JE, Choi YK, Kim HK, Kwon JH (2005) Pre-establishment of microwave-assisted extraction condition for antioxidative extracts from cabbage. Korean J Food Preserv 12: 62-67

Olaleye SB, Adaramoye OA, Erigbali PP, Adeniyi OS (2007) Lead exposure increases oxidative stress in the gastric mucosa of $\mathrm{HCl} /$ ethanol-exposed rats. World J Gastroenterol 13: 5121-5126

Owens MW, Grisham MB (1993) Nitric oxide synthesis by rat pleural mesothelial cells-induction by cytokines and lipopolysaccharide. Am J Physiol 265: L110-116

Park CK, Kwak YS, Hwang MS, Kim SC, Do JH (2007) Trends and prospect of ginseng products in market health functional food. Food Sci Ind 40, $30-45$

Park JH, Kim WY, Kim JM, Han SB, Lee SK, Kim ND, Park MK, Kim CK (2000) Steaming of ginseng at high temperature enhances biological activity. J Nat Prod 63: 1702-1704

Pravda J (2011) Crohn's disease: Evidence for involvement of unregulated transcytosis in disease etio-pathogenesis. World J Gastroenterology 17: $1416-1426$

Radi R, Beckman JS, Bush KM, Freeman BA (1991) Peroxynitrite-induced membrane lipid peroxidation: the cytotoxic potential of superoxide and nitric oxide. Arch Biochem Biophys 288: 481-487

Shen HM, Tergaonkar V (2009) NFkB signaling in carcinogenesis and as a potential molecular target for cancer therapy. Apoptosis 14: 348-363

Surh YJ, Keum YS, Park KK, Lee JM, Chun KS, Park JH, Lee SK, Kwon HJ (2000) Antioxidant and anti-tumor promoting activities of the methanol extract of heat-processed ginseng. Cancer Lett 150: 41-48

Velioglu YS, Mazza G, Gao L, Oomah BD (1998) Antioxidant activity and total phenolics in selected fruits, vegetables, and grain products. J Agric Food Chem 46: 4113-4117

Weisz A, Cicatiello L, Esumi H (1996) Regulation of the mouse inducibletype nitric oxide synthase gene promoter by interferon- $\gamma$, bacterial lipopolysaccharide and NG-monomethyl-L-arginine. Biochem J 316: 209-215 